\title{
The Consumer Experience of Responsibilization: The Case of Panera Cares
}

\author{
Giana M. Eckhardt ${ }^{1}$. Susan Dobscha ${ }^{2}$
}

Received: 13 March 2017 / Accepted: 17 January 2018 / Published online: 29 January 2018

(c) The Author(s) 2018. This article is an open access publication

\begin{abstract}
In this paper, we explore the consumer experience of responsibilization, wherein consumers are tasked with addressing social issues via their consumption choices. We study an approach to responsibilization which we label conscious pricing. Conscious pricing asks consumers to place a price on morality: How much would they pay for their lunch to combat the social issue of food insecurity? Conscious pricing stems from the broader movement of conscious capitalism, defined by its chief architects as an approach to business wherein the goal is to create value for all stakeholders: financial, ecological, ethical, and spiritual. Strategies such as conscious capitalism rely on consumers acting responsibly, assuming that consumers, when presented with the opportunity to "do good," will do so, and that consumers will prefer companies who provide them this opportunity. Using a case study approach and online reviews, in our analysis of Panera Cares, we find that consumers in fact experience discomfort when asked to address social issues via how much they choose to pay for their meal. Because food insecurity is embodied by homeless people eating with them in the café, eating in the café is perceived as unpleasant, and the homeless also feel demoralized. This discomposure leads consumers to resist the subject position of being responsibilized by not supporting the organization that is tasking them to do so. This study is the first empirical examination of the consumer experience of consumer responsibilization and allows us to contribute to a deepened understanding of consumer ethics.
\end{abstract}

Keywords Conscious capitalism · Conscious pricing $\cdot$ Consumer ethics $\cdot$ Consumer responsibilization · Corporate social responsibility · Panera Cares

\section{Introduction}

The consumer research literature has identified that consumers are now expected to address a wide variety of social issues through their individual consumption choices (e.g., global warming, income inequality), whereas in the past these issues would have been addressed structurally by governments, as part of a broader movement of individualization (Bardhi and Eckhardt 2017; Giesler and Veresiu 2014). Giesler and Veresiu (2014) outline how this consumer responsibilization within contemporary neoliberalism is

Giana M. Eckhardt

giana.eckhardt@rhul.ac.uk

Susan Dobscha

sdobscha@bentley.edu

1 School of Management, Royal Holloway, University of London, Egham, Surrey TW20 0EX, England, UK

2 Bentley University, 175 Forest St, Waltham, MA 02452, USA formed by supranational bodies such as the World Economic Forum (http://www.weforum.org/) through processes of personalization, authorization, capabalization, and transformation. Similarly, Humphreys and Thompson (2014) find that rather than companies, governments, and NGOs leading the way, providing solutions, and solving problems for social issues, consumers become the central problem-solving agent, with the perceived power coming from consumers' wallets.

Shamir (2008) makes the point that corporations, as well as individual consumers, have also become responsibilized. The most visible form of companies internalizing and implementing this logic is the conscious capitalism movement (Mackey and Sisodia 2014). Conscious capitalism argues that the purpose of any company is to make the world a better place - in addition to providing shareholder valueand that those noncompeting principles should be enacted at all levels and in all decisions in the organization, not just in a corporate social responsibility department. Conscious capitalist organizations are characterized by having a higher 
purpose, and being run by value-based leaders (O'Toole and Vogel 2011). For example, Unilever is trying to convert to this type of organization, with its vision statement now being "to make sustainable living commonplace" (Unilever Corporation 2014). John Mackey, CEO of Wholefoods, explains:

I believe that most of the greatest companies in the world also have great purposes... Having a deeper, more transcendent purpose is highly energizing for all of the various interdependent stakeholders, including the customers, employees, investors, suppliers, and the larger communities in which the business participates. (Marsh 2013)

A firm that is a prominent proponent of having this deeper, more transcendent purpose is TOMS, which has at its core a mission of "Improving Life," implemented by donating a pair of shoes to someone in need in a developing country every time a pair of shoes is purchased via its One for One policy (http://www.toms.com/improving-lives). Indeed, the company is featured in Bill Gates' 2008 Time Magazine interview on how to fix capitalism (Stengel 2008). Businesses such as TOMS rely on the consumer to make moral choices in the marketplace, a cornerstone of the responsibilization model, where it is assumed the consumer will want to act responsibly in order to support a corporation's efforts.

While we know how consumer responsibilization is formed-Caruana and Chatzidakis (2014) suggest that it is done through multiple agents, from NGOs to companies to governments to consumption communities and families, and Evans et al. (2017) confirm this by demonstrating that despite all those agents' involvement in responsibilizing the consumer to address the issue of food waste, and an enthusiastic embracing by companies (Mackey and Sisodia 2014) - there is scant evidence as to how consumers experience responsibilization. Soneryd and Uggla (2015) propose three responses that consumers may experience: indifference, which corresponds to the well-known finding that consumers tend to not make ethical choices in the marketplace (e.g., Devinney et al. 2010; Hassan et al. 2016); negotiating what is normal in terms of green behavior, for example when a practice such as recycling becomes a part of daily routines; and anti-consumption, where consumers attempt to limit their participation in the conventional economy by engaging in alternative means of consumption such as voluntary simplicity (Cherrier 2009). In all three of these responses, there is no questioning by the consumer that they should address social and environmental issues as an individual. That is, they buy into the subject position of being responsibilized. Can consumers resist the subject position itself?

In this paper, we explore how consumers experience being tasked with solving social issues through their consumption choices. That is, we examine the consumer experience of responsibilization. We do this in the context of
Panera Cares, a nonprofit division of Panera Bread Company, one of the largest café chains in the USA. Panera Cares self identifies as a conscious capitalist organization, making it an ideal context to study the effects of a company's desire to engage their consumers as moral agents in the fight against a social problem. They enact conscious capitalism through a pricing approach which we label conscious pricing. This incorporates elements of pay what you want (PWYW) (Gneezy et al. 2010), Pay It Forward (PIF) (Gray et al. 2014), and traditional charitable donation behavior (Winterich et al. 2013) by asking consumers to pay what they feel is appropriate for their food and drinks based on their support of the social issue of food insecurity, defined as people living with an intermittent or chronic fear that their food supply will run dry, to varying degrees (United States Department of Agriculture 2015). This pricing strategy allows us to understand how consumers put a price on morality. Pricing theory has been traditionally bounded within the economic and psychology paradigms, and has by and large ignored the fluid, dynamic, complex, socially impacted, and status-related nature of pricing (Noble and Gruca 1999; Lusch and Vargo 2014).

Our research question asks: How do consumers experience being tasked with responsibilization through their consumption choices? We identify that conscious pricing is one way in which consumer responsibilization is being implemented by companies. We then outline the consumer experience of responsibilization via how they experience conscious pricing within the context of Panera Cares cafés. We demonstrate that consumers feel discomfort with the conscious pricing policy. This discomfort takes three forms: physical, psychological, and philosophical. Consumers have disdain for the embodied experience of dining near the food insecure in the physical space of the café, and they question Panera Care's motives for engaging in conscious pricing. The food insecure experience discomfort as well. Rather than being empowered via a dignified dining experience, they feel ashamed or uncomfortable when trying to pay what they can for their food. Our findings suggest a pushback against tasked responsibilization. Resisting the subject position of being responsible for social issues via one's individual consumption behavior by not supporting the organization that is tasking them with it is a consumer response which is new to the literature. While anti-consumption or boycotting are forms of consumer resistance, they still operate under the logic that an individual's consumption behavior is the vehicle by which to make change; what we show here is consumers being fed up with that logic. We make several contributions to the literature. First, we contribute to the research on consumer responsibilization by extending Giesler and Veresiu (2014) and Soneryd and Uggla (2015) and explicating the three ways in which consumers push back against the logic of responsibilization. In addition, we 
critique conscious capitalism, building upon non-marketing critiques put forth by Fremeaux and Michelson (2016) and others. This builds upon previous critiques of business sustainability (Bradshaw and Zwick 2016) and corporate social responsibility (Chernev and Blair 2015). In the next section, we introduce the theories we will be turning toward to guide our understanding and analysis.

\section{Theoretical Foundations}

The most prominent way in which companies have embraced and tried to capitalize on consumer responsibilization is conscious capitalism. Here, we explore more in depth the ideology underlying this movement and the assumptions about consumption that it embodies.

\section{Conscious Capitalism}

Conscious capitalism believes that capitalism as an economic system can bring about positive social change if it is utilized mindfully (e.g., Sheth et al. 2011). Conscious capitalism was first declared a "megatrend" in 2007 (Aburdene 2007) and then went on to be popularized by Mackey and Sisodia (2014). It was developed in response to CSR initiatives not being as effective as companies had hoped they would be (Bradshaw and Zwick 2016; Fleming and Jones 2012; Laszlo and Brown 2014; Overman 2014). Even outlets such as the Wall Street Journal (Karnani 2010) have argued that continuing to believe CSR efforts will make a difference blinds us to potential real, structural solutions to the world's ills. In part, this is because there has not been a corresponding rise in $\mathrm{CnSR}$, or consumer social responsibility (Devinney et al. 2006; Caruana and Chatzidakis 2014; Vittel 2016). That is, while consumers say they would like companies to engage in socially responsible behavior, they themselves do not always engage in that behavior when they are making consumption decisions. Conscious capitalism purports to be able to succeed where CSR has not (see Fox 2011 for a detailed comparison between CSR and conscious capitalism).

Conscious capitalism was borne from John Mackey's, the CEO of Whole Foods, epiphany that "business and capitalism, while not perfect, were both fundamentally good and ethical" (Mackey and Sisodia 2014). As Simpson et al. (2013) point out, conscious capitalism is unapologetically capitalist; it does not seek to move away from the roots of a capitalist economic system. Yet, it is also a movement that seeks to integrate holistic principles such as mindfulness, quests for self-discovery, ethics, morality, and harmony into every realm of the organization. At its core, it is viewed as more than a standard business strategy and is instead an allencompassing philosophy that compels leaders to integrate its principles in all facets of the organization. It also is the ultimate expression of corporate responsibilization, putting an emphasis on individual, managerial, employee, and consumer responsibility rather than collective entities such as unions: "Our belief is that if a company does an outstanding job caring for its team members, creating value for them, and respecting them as key stakeholders, it can successfully avoid unionization" (Mackey and Sisodia 2014, p. 158).

Conscious capitalism is designed to be win-win for all stakeholders, including consumers (Mackey and Sisodia 2014). The four main tenets of conscious capitalism are:

1. Business is inherently good because it creates value.

2. It is ethical because it is based on voluntary exchange.

3. It is noble because it can elevate our existence.

4. It is heroic because it lifts people out of poverty and creates prosperity.

The goal of conscious capitalism is not to work toward sustainability via CSR programs, but rather to foster a flourishing organization via spirituality (Laszlo and Brown 2014). A flourishing organization is one connected to the community and the world, and its managers employ techniques such as meditation and journaling to be able to make decisions that will benefit everyone. As Sisodia (2014) explains, an organization should be fully human, which means that people are the purpose of the organization and loved ones are caring for loved ones, which is expected to result in better returns in the marketplace. Ultimately, a conscious capitalism organization puts consumers ahead of shareholders as the primary stakeholder group to be catered to (Rauch 2011). Since consumers are so elevated in this model, it is imperative to know how consumers experience conscious capitalism, which has not been researched to date.

Although conscious capitalism is a nascent movement, it has begun to be critiqued. For example, O'Toole and Vogel (2011) argue that it does not have the capability to be sustainable over time, and cannot meet the needs of all shareholders despite claiming to do so. These authors also argue that it is unrealistic to think that corporations could achieve an altruistic form of capitalism, and that government intervention will always be needed to address systemic social issues. The evidence as to whether consciously capitalist organizations perform better than other organizations is mixed. Simpson et al. (2013) show that they do, but Wang (2013) shows that they do not have higher profits nor do they have to spend less on marketing due to increased consumer loyalty, both of which are regularly claimed as features. Additionally, Fyke and Buzzanell (2013) point out that there are often tensions when conscious capitalism is implemented in an organization, as its adherents often fail to grapple with its ideological inconsistencies (the tension between consciousness and capitalism), and thus, despite 
best intentions, managers often still place more emphasis on capitalism over consciousness.

In sum, conscious capitalism assumes that organizations who apply the principles will automatically be the preferred brand in the category: "Conscious companies are loved by their customers, who are not just satisfied and loyal, but are also ardent fans and advocates. As a result, conscious companies generate very high sales," (Mackey and Sisodia 2014, p. 284). However, previous research has demonstrated that although consumers say they want companies to be socially responsible, their spending patterns do not necessarily reflect this (Devinney et al. 2010). Thus, it is not clear how consumers will react to this new breed of capitalism, which has consumer responsibilization assumed as a key component to its success. Chernev and Blair (2015) demonstrate that a company's CSR/prosocial initiatives can influence consumer perceptions of the company's offerings. Lee et al. (2017) examine consumer perceptions of organizations where the social mission is more prominent than the profit mission, and find that because communal norms are triggered, when these organizations are successful in the marketplace they are perceived as greedy. This suggests that the consumer reaction to conscious capitalism may not be as positive as the movement's founders expect it to be. The context in which we examine this is one in which the organization implements conscious capitalism principles via a pricing system that we label conscious pricing.

\section{Conscious Pricing}

Building upon Eckhardt and Dobscha (2014), we define conscious pricing as when consumers are asked to name their own price for some form of consumption in response to a social or moral issue. In examining the literature that exists on how consumers make pricing decisions when there is not a set price in a prosocial context, Gneezy et al. (2010) found that when a product had a fixed price, telling consumers that half of the revenue went to charity did not increase demand for the product. Yet when they could pay what they wanted, the belief that half the revenue went to charity greatly increased the amount they chose to pay. The authors conclude that consumers are willing to pay more in the PWYW situation because it minimizes suspicion of ulterior motives on the part of the company-a common occurrence with CSR programs - and also maximizes identity expressiveness (e.g., the cost of sending a bad signal "looms large," p. 326).

Pay It Forward (Gray et al. 2014) is another pricing strategy that more directly highlights an ethical or prosocial connection to the good or service purchased. To "pay it forward" is to be told upon entering into a financial transaction with a retailer that your purchase-meal or coffee, for example-has been paid for by a previous customer. You are then asked whether you would like to pay for the next customer's purchase. Thus, the transaction is framed as a gift. Whether or not consumers view it as a gift is not clear, but what is apparent from consumers engaging in PIF is that "PIF framing transforms the direct reciprocal relationship between the buyer and seller under pay-what-you-want pricing to a symbolically social relationship with other customers; the receiver and giver of a gift. In this way the direct exchange with the seller also takes on a symbolic social exchange," (Jung et al. 2014, p. 7). Panera Cares employs neither PWYW nor PIF, but rather a hybrid strategy, where they pair PWYW with a prosocial component, which we label conscious pricing. Customers are asked to name their own price for their food and drinks, to cover the costs of other people who may not be able to afford the posted price.

Panera Cares is implementing a conscious pricing strategy in order to accomplish two goals: to provide an opportunity for food secure consumers to act prosocially and to give food insecure consumers a haven to "dine with dignity." That is, instead of asking food secure consumers to donate to a food bank or place their change in a collection box at the point of purchase, the café chain is devoted to addressing hunger vis-à-vis food secure consumers paying extra for their meal. This approach is a direct result of Panera CEO Robert Shaich's adherence to the core components of conscious capitalism. Shaich believes that people are inherently good and will pay more than the displayed price for their meal if they can afford to do so, and thus, that this approach, in allowing consumers to demonstrate their "goodness" at the cash register, will result in a profitable business model (Braude and Eagen 2013).

In response to Eckhardt and Dobscha's (2014) call for research to extend our understanding of how consumers value what is enough to help others, and Soneryd and Uggla's (2015) call for more research to look into how people make sense of and respond to prescribed identities (p. 927), we investigate how consumers experience being tasked with responsibilization through their consumption choices, specifically the consumer experience of conscious pricing.

\section{Methodology}

To examine the consumer experience of consumer responsibilization via conscious pricing, we use the case study method (Burawoy 1998; Yin 2003). That is, we use a single case to expand upon, question, and alter theory. Yin (2003) points out that single cases are particularly relevant when the objective of the study is to answer "how" questions, and when the focus is on context to illuminate the phenomenon under study. We use a standard case study approach by examining company data such as annual reports, TED talks by the founder, and popular press articles about the organization. We also engaged in observation of the organizational visuals, such as on their 
Web site, as well as within one of the cafés itself (the Boston location), visited three times. Finally, we spoke with café management (again at the Boston location), all approaches as recommended by Yin (2003).

We also examined online reviews of all five Panera Cares cafés, using Kozinets' (2016) guidelines for online data collection and analysis. We used online reviews as they have proved to be a fruitful source of data within and outside of consumer research (Zhang et al. 2016; Wu 2013; Meredith 2016). Moreover, it has been shown that when asking consumers about their ethical consumption in face-to-face settings there are strong demand effects to appear socially conscious (Belk et al. 2005); thus, we wanted to access the consumer experience from a medium of expression where they could express themselves freely. As Kozinets (2016) notes, online reviews are a rich source of data in situations like this, as they "present consumers with a complex social communication environment, a conversation that grants them a sense of social presence as well as opportunities for a range of expressive and explanatory options," (p. 839).

The online reviews are from Yelp.com, the most widely used restaurant review site in the USA. Every review from all five cafés is analyzed. Of the five original cafés, two are still in operation: St Louis (called St. Louis Bread Company Cares, the original name of Panera), the first to open in 2010, and Boston, the last to open in 2013. The Chicago, Portland, Detroit, and St. Louis locations are now closed. There are a total of 281 reviews, with 123 from Chicago, 66 from Portland, 23 from St. Louis, 23 from Detroit, and 46 from Boston. Dates of reviews range from 2010 to 2017 . All reviewers posted only once, with one exception. Finally, while reviews are primarily from the food secure, there are also some from the food insecure, which allow us to examine the experience of conscious pricing from both perspectives.

We use an iterative, hermeneutic approach to analyze our corpus of data, which sees us going back and forth from the data to the literature to identify common themes (Spiggle 1994; Thompson et al. 1989). First, we present a brief introduction to Panera Cares, to provide the richness of context needed to understand the consumer experience, garnered from our case study analysis. Then, we outline the three ways consumers respond to responsibilization in this context, each of which includes the management vision and consumer response. Consumer responses are garnered from the online review data. We note that there was no notable difference in the responses of the food secure and insecure consumers, and thus, we report data from both groups to support our analysis.

\section{An Introduction to Panera Cares}

Panera Cares cafés are nonprofit versions of Panera Bread cafés. Panera Bread was founded by Ronald Shaich in 1981 and is considered a highly successful "quick casual" restaurant in North America, with 2014 cafés in the USA and Canada. Sales in 2016 topped \$US2.7b, and the company employs 44,400 people (Panera Bread Company 2016). Panera Bread is the number 10 fast food chain in the USA, and the only fast casual restaurant to break into the top 10 (QSR Magazine 2016). Panera Bread serves nearly 8.3 million customers per week and has the largest customer loyalty program in the industry, with approximately 22 million customers enrolled (Panera Bread Annual Report 2015). Shaich is considered one of the most successful restaurant entrepreneurs in history, having founded Au Bon Pain before selling it to found Panera Bread. The Panera Cares cafés exist to address the issue of food insecurity, in line with Conscious Capitalism beliefs about the higher purpose of organizations. How this is implemented relies heavily on Panera Bread. The Panera Bread and Panera Cares stores are virtually identical in terms of esthetics and branding: layout, menu, ordering process, food delivery system, employee training. The untrained eye would not be able to discern a Panera Cares until after they enter the retail storefront.

Panera Cares is designed to be financially self-sufficient, although that has not happened, as Panera Bread profits are still being used to financially support Panera Cares. Panera Cares cafés cover approximately $60-70 \%$ of their costs (Daks 2013). According to the company, $60 \%$ of customers leave the suggested price, $15-20 \%$ leave less or nothing, and 15-20\% leave more (http://www.paneracare s.org). However, the Boston Panera Cares café which we observed estimates that only $10 \%$ pay more than the suggested retail price. This estimate was borne out by the fact that four of the five Panera Cares have now been closed, and the remaining one continues to run at a loss.

Greeters called "Ambassadors" are situated at the front of the café to explain to the customers that when they get to the counter, they can pay what they want, and that the café is a nonprofit, as most people think they are in a Panera Bread rather than a Panera Cares. Greeters must be able to "diffuse potentially difficult situations," which as we will see arise fairly frequently when the food insecure eat at the restaurant. The food secure are encouraged to pay above what their meal is worth. Because the cafés tend to be overwhelmed with homeless people, the food insecure can only eat one entrée for free per week, and must earn it via $1 \mathrm{~h}$ of volunteering. To discern between the two groups, the greeter relies on consumer profiling, done solely via physical appearance and dress. Now that 
we have an understanding of what Panera Cares is and how it works, we can turn to examining the consumer experience of their conscious pricing system.

\section{The Consumer Experience of Conscious Pricing}

Our findings suggest that conscious pricing creates discomfort felt by both food secure and food insecure consumers. Shaich assumes that when given the opportunity to act ethically, consumers will appreciate this opportunity and engage in prosocial behavior. However, by and large, food secure consumers react negatively to conscious pricing. We outline the three types of discomfort felt: (1) food secure consumers felt physical discomfort when confronted with the physical proximity of the food insecure; (2) both food secure and insecure consumers experienced psychological discomfort; and (3) both groups felt a philosophical discomfort about the strategy that led to questioning the company's motives.

\section{Physical Discomfort}

Shaich envisions the Panera Cares experience to be one where regular, middle-class Panera Bread customers come in and eat with fellow middle class, white-collar workers who happen to be down on their luck. He explains his vision for the food insecure who will come to Panera Cares:

I remember one morning a guy comes in and says, 'listen, I was a tech writer. I lost my job six months ago. I don't know where my kids are going to eat tonight. We used to love to come to Panera. Can we eat here tonight?' That's why this place is here, come on in. (Braude and Eagen 2013)

Yet the typical food insecure clientele is not the out of work tech writer described above, but rather the chronically homeless living on the street. Thus, the food secure end up finding themselves confronted with the physical presence of the social issue they are being asked to address via how much they pay for their food. That is, the sanitized consumption space, where an expected experience that feels secure to consumers occurs (Debenedetti et al. 2013) and which they typically find in a Panera Bread, is disturbed. A review by BJK in Chicago is representative of how the food insecure are perceived:

Panera Cares $=$ enjoy the company of smelly, loud, and obnoxious vagrants while you eat. Screw this place, I'll never go to another Panera, ever. Set this crap up in a poor neighborhood. (BJ K, Chicago, 7/31/12, 1*)

Embodiment is the study of how the socially informed body engages with the objective structures of the predetermined world (Merleau-Ponty 1962). In consumer psychology, embodiment has been traditionally viewed as bodily responses to information and was studied in relation to judgment and decision making. Krishna and Schwarz (2014) state, "testing the breadth and ubiquity of embodiment effects is itself a valuable contribution to the body of phenomena that need accounting (p. 165)." More recently, consumer researchers have expanded the definition of embodiment to reflect how the body regulates our tastes and distastes and our compulsions and revulsions (Wacquant 2009; Thompson and Üstüner 2015). Joy and Sherry (2003) stress the importance of studying embodiment as it relates to consumer perceptions and interactions with marketing practices. The narrative above demonstrates the discomfort that consumers feel when confronted with the physical reality of dining next to the food insecure. Although most Panera Cares consumers profess to care broadly about the social problem of food insecurity, they are not comfortable with the very real experience of being proximal to those consumers. Like BJK, Bethany from Chicago describes the specific elements of embodiment that lead to physical discomfort (smell):

Sorry to be blunt, but you cannot eat or have coffee in peace here due to the fact that now that they give away food there are homeless (or very near to it) people sitting around. The woman at the table behind me smelled to high heaven. Giving food to those who can't afford it is a great concept, but I won't be back to patronize this restaurant - I paid, and I need to do work in a reasonable environment. Now, if they said we'll switch this and start donating to a soup kitchen, that's something I would allow them to "round up" my bill for. (Bethany H., Chicago, 7/24/2012, 1*)

Bethany experiences the space as "unreasonable" because there are homeless people in it. The food insecure are perceived as not belonging in a space like this. Bethany expresses a preference for a strategy that will eliminate undesirable embodiment such as donating to a soup kitchen. This is much closer to the successful TOMS model of conscious capitalism, where you buy a pair of shoes that is donated to a person in need in the third world, very physically far away from your own life and reality. As Murphy and Patterson (2011) point out, consumer behavior is directly connected with embodied practice; thus, this confrontation with the "other" is having a negative effect on consumers' experience of Panera Cares and undermining the potential for them to act responsibilized.

The food insecure are also not comfortable with eating in close proximity to the food secure. An important principle that undergirds the notion of serving a temporarily food insecure population, and providing dignity, is that of anonymity. That is, when getting food from a food bank, for 
example, one usually has to register. At Panera Cares, you are in a "regular" eating place, and no one will know how much you did or didn't pay for your meal except the cashier. The Boston Panera Cares manager explains the vision for anonymity in the cafés:

You can come in and it's pretty anonymous, you don't have to apply, nobody really has to know that you're struggling and I think that's the beauty of this café. Anybody's welcome to come in any time to get lunch or bread to take home to help out with, you know, the food situation whatever that may be at their home. What we are aiming for is a dignified dining experience so all may eat with dignity. (Boston manager)

Yet the reality within the cafés differs from this, and because of the proximity to food secure customers, results in discomfort stemming from physical proximity. Vanessa narrates,

I took my mother into Panera Cares today because she just moved to town and is on a very low fixed income. When the total suggested price was given my mother put the money she could afford into the box. The cashier watched her and said "we can do a discount once but if you come back this week you'll have to pay full price. We only do a discount once a week here." This was said with others behind us and very loudly. That is not posted anywhere in the store. My mother stood mortified and near tears as we walked away and waited. (Vanessa H., Portland, 11/16/2014, 1*).

The fact that Vanessa's mother was acknowledged as food insecure in front of "the others behind us" made her "mortified and near tears." In this case, Vanessa's mother is most likely close to Shaich's vision of the person with middleclass values but down on their luck coming in for a meal. Yet the cashier articulates the rules out loud, so that the nearby food secure customers can hear, breaking the anonymity that this system is meant to provide for the food insecure.

In sum, the conscious pricing system allows for the food secure and food insecure to eat in close physical proximity to each other in the Panera Cares cafés, which leads to undesirable embodiment of the other. This mutual discomfort reflects previous research on embodiment that shows "facilitating or impairing a person's bodily response to a stimulus also facilitates or impairs the person's subjective experience of the stimulus (Krishna and Schwarz 2014, p. 161)." In this case, both the food secure and food insecure's subjective experience of conscious pricing was negative, and this experience leads both groups to think less of the brand. Physical distance was preferred and suggested as a better alternative. Several consumers stated a clear preference for donating money to a soup kitchen, where the food insecure would be physically distant, instead.

\section{Psychological Discomfort}

In addition to physical discomfort, consumers were also uncomfortable with other non-physical dimensions of conscious pricing in Panera Cares, including the social comparison with other consumers that takes place and the consumer profiling that the café employees engage into determine who is food secure and food insecure, which we label psychological discomfort. First, in the café, consumers monitor the donation behavior of other consumers. This type of social comparison among consumers is common in the marketplace (Moschis 1976; Bearden and Rose 1990). In this case, social comparison takes the form of noticing how much other customers are paying, and interpreting the amount, if it is low, as free rider behavior.

The last time I went, the lady in front of me ordered about \$20 worth of food and did not make a donation of any kind. Another family had large meals and breadto-go bags and they also made no donation. I made my round up donation but I felt taken advantage of and I haven't been back since. (H D., Chicago, 1/13/13, $1^{*}$ )

HD expresses the idea that when someone pays more than the listed price for their food, she feels taken advantage of, because she perceives those who make no "donation" as free riders in the system. This is an example of the tragedy of the commons (Hardin 1968), wherein individuals do not want to contribute their fair share to the common good, thus resulting in free riders, and the assumption that everyone is trying to be a free rider. Social comparison can be a strong predictor of donation behavior (Croson and Shang 2008; Shang et al. 2008). The presence of other consumers, particularly ones that reflect one's self-identity, has been shown to increase contribution amounts. However, in this context, the effects of social comparison result in psychological discomfort because consumers are monitoring others to see whether they are free riders.

Additionally, employees engage in a rudimentary profiling system to distinguish between food secure and insecure customers which results in discomfort by both groups:

If they think you are solidly middle class they will treat you with respect; the lower they perceive your income level to be, the worse you can expect to be treated. If you run a card, which is my typical form of payment, the cashier will always ask if you want to round up to help somebody else. I did this with each purchase for several months. But then I saw how people were treated when they tried to get food for less than the posted price. They are questioned, spoken down to, sometimes shouted at and often refused. (I think this probably violates their $501 \mathrm{c} 3$ status, but I'm definitely not a lawyer. But they do get a tax exemption 
based on a PAY WHAT YOU CAN financial model.) Somebody offering \$2-3 shouldn't be turned away. I just don't like seeing people treated that way, and I felt duped, because I had been donating money, hoping to help the same people Panera Cares were treating like s\#! \%. I sat near a pair of managers one day while they were talking with some sort of community organizer and their language disgusted me. They say that they are only helping "people who are trying to help themselves." This is apparently determined at a glance, because if they think you are not doing enough to improve your station, they will come down on you in a mean, and very public display. It is appalling. I've seen staff walk through the café giving free baguettes to people- but the only people who received them were dressed nicely, with their hair made up. (Chris R., Portland, 9/22/2014, 1*)

The profiling that Panera Cares engages in is perceived negatively by Chris in his narrative above. In particular, how the food insecure look plays an important role. On the one hand, if they look presentable, they fulfill the temporarily food insecure profile that Panera Cares wants to cater to, and are more likely to be treated with dignity. On the other hand, by virtue of looking presentable, they are also questioned as to why they cannot pay more.

In sum, consumers feel uncomfortable with the social comparison and profiling which regularly occur in Panera Cares, and this results in psychological discomfort. Similar to physical discomfort, this results in consumers having a bad experience and expressing it in their online reviews. This again reinforces a push back against the subject position of responsibilization, in that there is an active questioning of how and why how much an individual chooses to pay for their food is the right way to address food insecurity, and expressed intentions not to patronize the brand anymore because of their discomfort. In the next section, we highlight the third type of discomfort that was evident in our data set: philosophical discomfort, that is, questioning the motives behind conscious pricing and how it is implemented.

\section{Philosophical Discomfort}

There was also discomfort with motives and tactics behind the conscious pricing model, which we label philosophical discomfort. That is, consumers were uncomfortable with the general philosophy behind what Panera Cares was doing and how they were doing it. This manifested itself in two ways: discomfort with how the conscious pricing policy is explained and questioning the motives of the parent company, Panera Bread. Philosophical discomfort expands the scope of what people are uneasy with to the company at large.
For many consumers, the initial explanation of the pricing system by the greeter was off putting:

I love Panera and thought this was a great idea but it was an awful experience and although I work less than a block away will never ever go back. They were extremely pushy in making me pay ABOVE the suggested price to "donate" for others. So I paid a \$1 extra and they were so rude like that's all I could give. Really? Yeah that is all I can give actually no I shouldn't have given at all. I'd rather choose who my donations go to then give it to a bunch of pushy employees who claim it goes to the needy. Thanks but no thanks, Panera. (S M, Boston, 6/11/2013, 1*)

Here we see SM uncomfortable with the overall implementation of the conscious pricing system vis-à-vis his interaction with the greeter. He was made to feel like his "donation" was not enough, and also feels like he should be able to choose where his donations go rather than being strong-armed in the moment by the employees at Panera Cares. Finally, we can see a questioning of the claims of Panera Cares when SM says the employees "claim" the extra money goes to the needy. This questioning of the motives behind the conscious pricing policy was prevalent in our data set. Here we see Chris describe Panera Cares as an "obvious marketing gimmick":

This place is an obvious marketing gimmick by offering you the opportunity to pay more than the regular price or less, depending on how "needy" they think you are. As you'd imagine, it is human nature to find loopholes in this system, so it probably doesn't really work out the ideal give-and-take way. BUT, Panera gets good publicity for the idealistic goal, and new customers who might try the food at lower price points! Win-win situation! You can knock it for whatever you want, but in the end, you can always pay whatever you want to get a 5-star value;) I'm going to save a lot of money by keeping this in my lunch rotation. Yeah, go ahead and hate me. If you think you're so generous, then go donate money to an actual charity that puts it to better use by feeding the legitimately needy on lower-cost foods, rather than giving extra money to a place that gives the needy discounts on overpriced sandwiches for the sake of elevating brand image. (Chris M., Boston, 8/7/2013, 5*)

Here Chris comments on the fact that the food at Panera Cares is relatively expensive, given that it is targeted to a middle-class audience, and thus, letting the food insecure eat there for less than the advertised cost is perhaps not the most efficient way to feed the hungry. He concludes that all this is done for the sake of "elevating brand image" and questions the legitimacy of the café as a charity. We can see 
this echoed in Victor's comments: "This is just a fancy tax shelter version of food recycling for Panera." (Victor K., Chicago, 2/8/2015, $1^{*}$ ) as well as Jon's: "It's obvious what Panera Cares is about is positive PR for their other locations in upscale suburbs where clients do not have to wade through filth for lunch." (Jon T., Portland, 9/21/2014, $1^{*}$ ). Consumers are using such words as tax shelter and PR (public relations) to describe the cafés. These negative reviews go beyond experiential aspects of being in the café; they critique the motives of the company. De Chematony et al. (1998) found that consumer perceptions of a company's perceived motives were correlated with its success or failure, and our analysis suggest there is a perceived inauthenticity of the company's motives.

Our observations also bear out where this questioning of motives might be stemming from. For example, the manager of the Boston Panera Cares describes their policy regarding dress code for the food insecure, as an effort to maintain a sanitized consumer experience within the cafés:

You have to meet a hygiene and health code. You have to meet a dress code. You have to have tennis shoes because it's a safety issue. You can't come in in gym pants. There are checkmarks and standards that we have to address those issues. (Boston Panera Cares manager)

Yet, based on our observations, there are plenty of food secure diners dressed in the forbidden attire (sweatpants, flip flops); in particular students. It becomes clear when you are inside a Panera Cares that there are two levels of standards: one for the food secure and one for the food insecure, which can lead one to experience discomfort with the policies in general. Indeed, this philosophical discomfort can lead consumers to "test" the system. Paul explains:

I wasn't too thrilled with the experience. I thought it felt more like finding out what I had in my pocket and then telling me what I can afford. No. Actually it was like that. The suggestion was asking me how much money I had and then telling me what I can get. I pretended to have a dollar. I was told I could get a cup of coffee. I would have went to McDonald's. I actually had more money. Just testing the system to see how much crap big business can put forward. Wrote them they never got back. What is the loss of one customer for life? (Paul B., Chicago, 10/12/2014, 1*)

Paul perceives Panera Cares as trying to find out how much he has-is he food secure or insecure?-and then treating him accordingly. In this case, because he decided to test the system and said he only had one dollar, they treated him as a food insecure person and told him he could only have a coffee. Paul sums up this experience as "crap big business puts forward." In sum, questioning the motives of the company and the ways in which its policies are implemented lead to consumers resisting being asked to participate in the system, e.g., "what is the loss of one customer for life?"

Overall, this questioning of the motives and tactics of Panera Cares (a nonprofit) may be intensified because of the close connection it has to its for-profit parent company, Panera Bread. Lee et al. (2017) argue that the distinction between companies that have a social mission versus those who have a profit mission is salient for consumers, and in the case of Panera Cares and Bread, is not clear. A nonprofit orientation can paradoxically drive consumer perception of organizational greed. This is because communal norms rather than exchange norms are invoked by consumers, and any perceived breach of communal norms is seen as an indication of greed. As we saw with customers using terms like tax haven and marketing gimmick to describe Panera Cares, this effect seems to be at play here.

\section{Conclusion}

To summarize the consumer experience for all three types of discomfort, for both the food secure and the food insecure, most Panera Cares consumers experienced conscious pricing in a way that differed from Panera's expectations. Consumers had resentment toward Panera Cares because of the way they were tasked to perform a prosocial behavior. Their discomfort with being asked to engage with the conscious pricing system ranged from a physical discomfort with the presence of food insecure consumers to a philosophical discomfort with the way in which the Panera parent company appears (to them) to be leveraging this nonprofit arm of Panera Cares to boost brand equity. Enacting responsibilization at the point of purchase isn't always so routinely criticized (think about being asked to donate money at the cash register of a grocery store), but Panera's concept of conscious pricing fostered an environment of discomfort. The discomfort created by the mingling of food secure and food insecure leads to a negative consumption experience where there is tension between the sanitized experience both the consumers and the company want and the difficulties in implementing responsibilization strategies that rely on consumer participation to succeed. In the end, the goals of providing a place for the food insecure to dine with dignity and the food secure to act responsibly are not met.

\section{Discussion}

This case could stand on its own as an example of the failures of conscious capitalism to deliver on its core principle that companies can do well for their stakeholders and do good for society. On a company level, four out of the five Panera Cares cafés have ceased operations. Additionally, Panera 
Bread, the parent company, was recently bought by JAB, a German conglomerate who owns Krispy Kreme donuts, among other companies (http://fortune.com/2017/04/05/ why-panera-bread-founder-sold/). Whole Foods has also recently been purchased by Amazon, a company not known for its enlightened business practices (http://www.cnn. com/2017/06/29/opinions/amazon-whole-foods-perroneopinion/index.html).

It is becoming clear that conscious capitalism is not playing out in the marketplace as the founders of the movement expected it to. Yet, this is not a managerial story of misguided execution. Rather, the Panera Cares context allows us to see how consumers who are responsibilized experience it in the marketplace, and the complexities and unintended consequences that can arise from implementing a philosophy that relies on assumptions about consumers which are not always borne out. Investigating the experience of conscious pricing allows us to see at a microlevel what some of the consequences of the individualized responsibilization of the consumer can look like, and what effect on companies it can ave.

\section{Tasking the Marketplace with Responsibilization}

The case of Panera Cares provides a fruitful context to understand how one company attempted to apply conscious capitalism principles to a social problem and found consumer resistance toward being tasked with addressing social issues such as hunger and homelessness through their individual consumption. Responsibilization practices, driven by conscious capitalism and other prosocial management principles, require not only corporate commitment but also consumer buy-in. Companies who apply these strategies assume their consumers will automatically and eagerly participate in the opportunity to do good. In reality, responsibilization is a highly complicated phenomenon, and our analysis shows that buy-in is minimal. In fact, Arvidsson and Peitersen (2013) suggest that the responsibility for social problems cannot be solved by individual companies. Thus, while conscious capitalism is being hailed as an innovation in how organizations should orient themselves due to the lack of effectiveness of many CSR programs, the ultimate failure of Panera Cares strongly suggests that this approach may not be any more effective in harnessing consumer social responsibility than previous efforts (Devinney et al. 2006; Caruana and Chatzidakis 2014; Vittel 2016).

More and more, societies are relying on the marketplace to provide solutions to social problems. These marketplace solutions, responsibilization, are in some cases replacing the efforts of government agencies and NGOs (Giesler and Veresiu 2014; Shamir 2008). Conscious capitalism, as described in the literature review, is but one contemporary application of responsibilization. While Giesler and Veresiu 2014 outline how companies are replacing NGOs in order to establish, maintain, and promote responsibilization strategies, the need to understand how consumers experience these strategies is paramount to assessing whether or not responsibilization can be a powerful tool for change. This marketization of social problems has been taken up in religious studies, as scholars have begun to investigate how these enlightened capitalist enterprises are replacing, in addition to NGOs and government agencies, traditional religious entities, such as mosques, temples, or churches. Fremeaux and Michelson (2016) point out that conscious capitalism as a movement vaguely resembles Christian values. For example, many food banks, criticized by Shaich as not providing dining with dignity for the food insecure, are run by churches. Our field notes from attending the opening of the Boston Panera Cares note that many figures from the charitable sector of Boston society were invited to attend, and the priest, whom the first author was seated next to, and who ran one of the largest food banks in the city, took umbrage to church food banks being referred to as "undignified."

Similarly, Ponte and Richey (2014) point out that TOMS shoes has become the conscious brand of note for many American millennials as they feel good after purchasing shoes. This positive feeling is bolstered by the photos of poor people being given shoes by typically white, privileged Americans, while the realities of the work conditions of the shoe makers is backgrounded or hidden from their view. Hulsether (2013), in discussing TOMS shoes as an example of conscious capitalism, points out that the meaning of consumer spending - buying a pair of shoes-has been altered to now being associated with engaging in charity and cultivating morals, areas typically associated with religious organizations. She questions whether this shift is a positive one. We add to this line of critique by bringing in insights from a consumer research perspective. That is, we demonstrate that consumers question the methods by which organizations are turning markets into moral marketplaces in three ways: via the physical, the psychological, and the philosophical. We discuss these reactions in the following section.

\section{Consumer Experience of Responsibilization}

Panera Cares' particular brand of responsibilization assumed that consumers would overwhelmingly respond positively to the opportunity to act prosocially. Food secure consumers were immediately put off by the responsibilization mandate of making a snap decision about their level of interest and commitment to the extremely complex problem of food insecure. Food secure consumers also felt that by implementing the conscious pricing system, the company was compromising the familiarity, authenticity, and security (Debenedetti et al. 2013) that consumers want from a "typical" Panera 
experience. Our study of the discomfort felt as a result of this upheaval of familiarity, authenticity, and security extends the discourse on how consumers respond when being tasked with responsibilization. Compromising these comforting elements in the retail space created discomfort among their consumers. It created cognitive dissonance that negatively impacted the rest of their dining experience. Psychological discomfort quickly morphed to a discomfort with the proximity of food insecure consumers, who embodied a very different type of food insecure consumer than what Shaich envisioned when he created this concept. Ultimately, consumers translated this short-term, proximal discomfort to a grander discomfort with the company itself. In short, consumers tasked with responsibilization combined with the violation of norms of space as outlined above, responded by expressing their discomfort, not returning to the cafés, and ultimately negatively viewing the brand.

This research highlights the need for retailers to understand the crucial importance of consistency of physical space not just in terms of familiarity and authenticity, but also in terms of embodiment. Embodiment is not merely a bodily reaction to information (Krishna and Schwarz 2014) but is crucially tied to social factors such as norms, roles, values, and culture (Joy and Sherry 2003). In his discussion of the "holistic consumer experience," Tsai (2005) states, "all marketing efforts should be directed at creating a holistic brand value structure, corresponding to the expectations and aspirations of consumers on the cognitive, affective, and social levels (p. 437)." Specifically, he implores marketers to create congruency between the physical space in which the product is produced and marketed and the consumer's existing mental heuristic to enhance the consumer experience. This study provides empirical evidence for what happens if this congruency is not maintained. Failure to acknowledge the critical importance of embodiment as it relates to the consumer experience results in a discomfort with the brand that moves beyond the immediate environment, thus bleeding into the consumer's perception of the brand.

Our research also extends Soneryd and Uggla (2015), who propose three responses that consumers may have when tasked with responsibilization: indifference, negotiating what is normal, and engaging in anti-consumption. We go beyond this by demonstrating that consumers can resist the subject position being forced upon them. This is supported in the data in the form of (a) resisting the task of acting responsibly, (b) resisting the notion that responsibilization would bring about wide-scale change or solutions to complex social problems, and (c) resisting the motives of the company. Relatedly, Lee et al. (2017) have suggested more research is needed to understand when consumers will credit organizations for simultaneously doing good (for society) and doing well (for their shareholders). They argue that when an organization's social mission is prominent relative to a profit mission, it triggers communal norms rather than exchange norms. Thus, if communal norms are violated, there is a perception of greed. Our study supports this conclusion and also shows the need for understanding consumer responses when the company implements a "hybrid" doing good/doing well strategy as in Panera Cares.

\section{Compliance with Ethical Standards}

Ethical Approval All procedures performed in studies involving human participants were in accordance with the ethical standards of the institutional and/or national research committee and with the 1964 Helsinki Declaration and its later amendments or comparable ethical standards.

Open Access This article is distributed under the terms of the Creative Commons Attribution 4.0 International License (http://creativeco mmons.org/licenses/by/4.0/), which permits unrestricted use, distribution, and reproduction in any medium, provided you give appropriate credit to the original author(s) and the source, provide a link to the Creative Commons license, and indicate if changes were made.

\section{References}

Aburdene, P. (2007). Megatrends 2010: The rise of conscious capitalism. Charlottesville, VA: Hampton Roads Publishing.

Arvidsson, A., \& Peitersen, N. (2013). The ethical economy: Rebuilding value after the crisis. New York City: Columbia University Press.

Bardhi, F., \& Eckhardt, G. M. (2017). Liquid consumption. Journal of Consumer Research. https://doi.org/10.1093/jcr/ucx050.

Bearden, W. O., \& Rose, R. L. (1990). Attention to social comparison information: An individual difference factor affecting consumer conformity. Journal of Consumer Research, 16(4), 461-471.

Belk, R. W., Devinney, T., \& Eckhardt, G. (2005). Consumer ethics across cultures. Consumption Markets \& Culture, 8(3), 275-289.

Bradshaw, A., \& Zwick, D. (2016). The field of business sustainability and the death drive: A radical intervention. Journal of Business Ethics, 136(2), 267-279.

Braude, J., \& Eagen, M. (2013). Interview with Ron Saich and Giana Eckhardt. Boston Public Radio, 8 January, http://wgbhnews.org/ post/jim-braude-and-margery-eagan-occupy-bpr-0.

Burawoy, M. (1998). The extended case method. Sociological Theory, 16(1), 4-33.

Caruana, R., \& Chatzidakis, A. (2014). Consumer social responsibility (CnSR): Toward a multi-level, multi-agent conceptualization of the "other CSR". Journal of Business Ethics, 121(4), 577-592.

Chernev, A., \& Blair, S. (2015). Doing well by doing good: The benevolent halo of corporate social responsibility. Journal of Consumer Research, 41(6), 1412-1425.

Cherrier, H. (2009). Disposal and simple living: exploring the circulation of goods and the development of sacred consumption. Journal of Consumer Behaviour, 8(6), 327-339.

Croson, R., \& Shang, J. Y. (2008). The impact of downward social information on contribution decisions. Experimental Economics, 11(3), 221-233.

Daks, M. (2013). Pay what you can concept challenged by thin margins. The Non Profit Times, December 31, http://www.thenonprof ittimes.com/news-articles/pay-what-you-can-concept-challenged -by-thin-margins/. 
de Chematony, L., Dall'Olmo Riley, F., \& Harris, F. (1998). Criteria to assess brand success. Journal of Marketing Management, 14(7), 765-781.

Debenedetti, A., Oppewal, H., \& Arsel, Z. (2013). Place attachment in commercial settings: A gift economy perspective. Journal of Consumer Research, 40(1), 904-923.

Devinney, T. M., Auger, P., \& Eckhardt, G. M. (2010). The myth of the ethical consumer. London: Cambridge University Press.

Devinney, T. M., Auger, P., Eckhardt, G., \& Birtchnell, T. (2006). The other CSR: Consumer social responsibility. In Stanford Social Innovation Review, Fall, pp. 30-37.

Eckhardt, G. M., \& Dobscha, S. (2014). The effectiveness of conscious pricing in promoting social sustainability. Recherche et Applications en Marketing, 29(3), 103-106.

Evans, D., Welch, D., \& Swaffield, J. (2017). Constructing and mobilizing 'the consumer': Responsibility, consumption and the politics of sustainability. Environment and Planning A, 49(6), 1396-1412.

Fleming, P., \& Jones, M. (2012). The end of corporate social responsibility: Crisis and critique. Thousand Oaks, CA: Sage.

Fox, J. (2011). The HBR Interview: What is it that only I can do?" Harvard Business Review, January/February, https://hbr.org/2011/01/ the-hbr-interview-what-is-it-that-only-i-can-do.

Fremeaux, S., \& Michelson, G. (2016). The common good of the firm and humanistic management: Conscious capitalism and economy of communion. Journal of Business Ethics, 145, 701-709.

Fyke, J., \& Buzzanell, P. (2013). The ethics of conscious capitalism: Wicked problems in leading change and changing leaders. Human Relations, 66(12), 1619-1643.

Giesler, M., \& Veresiu, E. (2014). Creating the responsible consumer: Moralistic governance regimes and consumer subjectivity. Journal of Consumer Research, 41(3), 840-857.

Gneezy, A., Gneezy, U., Nelson, L. D., \& Brown, A. (2010). Shared social responsibility: A field experiment in pay-what-you-want pricing and charitable giving. Science, 329(5989), 325-327.

Gray, K., Ward, A. F., \& Norton, M. I. (2014). Paying it forward: Generalized reciprocity and the limits of generosity. Journal of Experimental Psychology, 143(1), 247-254.

Hardin, G. (1968). The tragedy of the commons. Science, 162(3859), $1243-1248$.

Hassan, L., Shiu, E., \& Shaw, D. (2016). Who says there is an intention behavior gap? Assessing the empirical evidence of an intentionbehavior gap in ethical consumption. Journal of Business Ethics, 136, 219-236.

Hulsether, L. (2013). TOMS shoes and the spiritual politics of neoliberalism. http://religionandpolitics.org/2013/10/01/toms-shoes -and-the-spiritual-politics-of-neoliberalism/.

Humphreys, A., \& Thompson, C. J. (2014). Branding disaster: reestablishing trust through the ideological containment of systemic risk anxieties. Journal of Consumer Research, 41, 877-910.

Joy, A., \& Sherry, J. F. (2003). Speaking of art as embodied imagination: A multisensory approach to understanding aesthetic experience. Journal of Consumer Research, 30(2), 259-282.

Jung, M. H., Nelson, L. D., Gneezy, A., \& Gneezy, U. (2014). Paying more when paying for others. Journal of Personality and Social Psychology, 107(3), 414.

Karnani, A. (2010). The case against corporate social responsibility. Wall Street Journal, 23, 1-5.

Kozinets, R. V. (2016). Amazonian forests and trees: Multiplicity and objectivity in studies of online consumer-generated ratings and reviews, a commentary on de Langhe, Fernbach, and Lichtenstein. Journal of Consumer Research, 42(6), 834-839.

Krishna, A., \& Schwarz, N. (2014). Sensory marketing, embodiment, and grounded cognition: A review and introduction. Journal of Consumer Psychology, 24(2), 159-168.

Laszlo, C., \& Brown, J. (2014). Flourishing enterprise: The new spirit of business. Redwood City, CA: Stanford University Press.
Lee, S., Bolton, L. E., \& Winterich, K. P. (2017). To profit or not to profit? The role of greed perceptions in consumer support for social ventures. Journal of Consumer Research, 44, 853-876.

Lusch, R. F., \& Vargo, S. L. (2014). The service-dominant logic of marketing: Dialog, debate, and directions. London: Routledge.

Mackey, J., \& Sisodia, R. (2014). Conscious capitalism: Liberating the heroic spirit of business. Cambridge, MA: Harvard Business Review Press.

Marsh, R. (2013). 11 Inspiring quotes for small business from John Mackey. https://www.logomaker.com/blog/2013/03/25/11-inspi ring-quotes-for-small-business-from-john-mackey/.

Meredith, J. (2016). Using conversation analysis and discursive psychology to analyse online data. In D. Silverman (Ed.), Qualitative research (pp. 261-276). London: Sage.

Merleau-Ponty, M. (1962). Phenomenology of Perception [Phénoménologie de la Perception]. London: Routledge \& Kegan Paul.

Moschis, G. P. (1976). Social comparison and informal group influence. Journal of Marketing Research, 13, 237-244.

Murphy, S., \& Patterson, M. (2011). Motorcycling edgework: A practice theory perspective. Journal of Marketing Management, 27(13-14), 1322-1340.

Noble, P. M., \& Gruca, T. S. (1999). Industrial pricing: Theory and managerial practice. Marketing Science, 18(3), 435-454.

O'Toole, J., \& Vogel, D. (2011). Two and a half cheers for conscious capitalism. California Management Review, 53(3), 60-76.

Overman, S. (2014). Conscious economy: How a mass movement for good is great for business. London: Routledge.

Panera Bread Annual Report. (2015). Accessed 30 June 2016 http:// www.panerabread.com/en-us/company/financial-reports.html

Panera Bread Company. (2016). Annual report. http://search.proqu est.com/docview/230595009? accountid $=8576$.

Ponte, S., \& Richey, L. (2014). Buying into development? Brand aid forms of cause related marketing. Third World Quarterly, $35(1), 65-87$.

Rauch, D. (2011). Conscious capitalism: A better road map: A response to James O'Toole and David Vogel's 'Two and a Half Cheers for Conscious Capitalism'. California Management Review, 53(3), 91-97.

Shamir, R. (2008). The age of responsibilization: On market embedded morality. Economy and Society, 37(1), 1-19.

Shang, J., Reed, A., \& Croson, R. (2008). Identity congruency effects on donations. Journal of Marketing Research, 45(3), 351-361.

Sheth, J. N., Sethia, N. K., \& Srinivas, S. (2011). Mindful consumption: A customer-centric approach to sustainability. Journal of the Academy of Marketing Science, 39(1), 21-39.

Simpson, S., Fischer, B., \& Rohde, M. (2013). The conscious capitalism philosophy payoff: A qualitative and financial analysis of conscious capitalism corporations. Journal of Leadership, Accountability and Ethics, 10(4), 19-29.

Sisodia, R. (2014). Building fully human organizations. http://www. consciouscapitalismfl.org/raj-sisodia-on-building-fully-human -organizations/.

Soneryd, L., \& Uggla, Y. (2015). Green governmentality and responsibilization: New forms of governance and responses to 'consumer responsibility’. Environmental Politics, 24(6), 913-931.

Spiggle, S. (1994). Analysis and interpretation of qualitative data in consumer research. Journal of Consumer Research, 21(3), 491-503.

Stengel, R. (2008). Bill gates: How to fix capitalism. http://conte nt.time.com/time/video/player/0,32068,1697222543_18278 38,00.html.

The QSR 50: The top 50 brands in quick service and fast casual. In http://www.qsrmagazine.com/reports/qsr50-2015-top-50-chart . Accessed 15 Oct 2015.

Thompson, C. J., Locander, W. B., \& Pollio, H. R. (1989). Putting consumer experience back into consumer research: The philosophy 
and method of existential-phenomenology. Journal of Consumer Research, 16(2), 133-146.

Thompson, C. J., \& Üstüner, T. (2015). Women skating on the edge: Marketplace performances as ideological edgework. Journal of Consumer Research, 42(2), 235-265.

Tom's-Improving Lives. (2013). http://www.toms.com/improving-lives . Accessed 15 June 2013.

Tsai, S. (2005). Integrated marketing as management of holistic consumer experience. Business Horizons, 48, 431-441.

Unilever Corporation. (2014). Mission Statement. http://www.unilever. com/about/who-we-are/our-vision/

United States Department of Agriculture. (2015). Food Security in the U.S. Washington, DC: Economic Research Service.

Vittel, S. (2016). A case for consumer social responsibility (CnSR): Including a selected review of consumer ethics/social responsibility literature. Journal of Business Ethics, 130, 767-774.
Wacquant, L. (2009). The body, the Ghetto and the Penal State. Qualitative Sociology, 32(1), 101-129.

Wang, C. (2013). Conscious capitalism firms: Do they behave as their proponents say? California Management Review, 55(3), 60-86.

Winterich, K., Mittal, V., \& Aquino, K. (2013). When does recognition increase charitable behavior? Toward a moral identity-based model. Journal of Marketing, 77(3), 121-134.

Wu, P. F. (2013). In search of negativity bias: An empirical study of perceived helpfulness of online reviews. Psychology \& Marketing, 30(11), 971-984.

Yin, R. K. (2003). Case study research: Design and methods (3rd ed.). Thousand Oaks, CA: Sage.

Zhang, L., Wu, L., \& Mattila, A. S. (2016). Online reviews: The role of information load and peripheral factors. Journal of Travel Research, 55(3), 299-310. 